\title{
THE STRUCTURE OF EUROPEAN INDUSTRY
}

\begin{abstract}
ANNOUNCEMENT
The present volume of essays on the Structure of European Industry, appears as volume 1 of the new series: Studies in Industrial Organization, the successor to the Nijenrode Studies in Economics. The latter series had three volumes with studies in industrial organization economics, which appeared between 1976 and 1978. The new series will seek to accomplish the same goal as the former one, namely to promote the interest in and understanding of the problems of economic organization, especially from an international point of view. The good reception with which the previous volumes have been met has encouraged the Advisory Board, the Board of Editors, and the Publishers to continue, though not in liaison with the name of a particular institution.
\end{abstract}




\title{
STUDIES IN INDUSTRIAL ORGANIZATION
}

\author{
Volume 1
}

Advisory Board

Professor W. Adams, Michigan State University, East Lansing, Michigan, USA.

Professor R.E. Caves, Harvard University, Cambridge (Mass.), USA.

Professor K.D. George, University College, Cardiff, United Kingdom.

Professor E. Heusz, Friedrich Alexander University, ErlangenNürnberg, West Germany.

Professor H.W. Lambers, Erasmus University, Rotterdam, The Netherlands.

Professor R. Prodi, University of Bologna, Bologna, Italy.

Professor W.G. Shepherd, University of Michigan, Ann Arbor, Michigan, USA.

Professor T. Wilson, University of Glasgow, Glasgow, United Kingdom.

Board of Editors

Professor A.P. Jacquemin, University of Louvain, Belgium.

Professor H.W. de Jong, University of Amsterdam, The Netherlands. 


\title{
The Structure of \\ European Industry
}

\author{
editor \\ H.W. de Jong
}

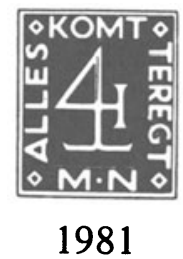

MARTINUS NIJHOFF PUBLISHERS

THE HAGUE/BOSTON/LONDON 


\section{Distributors:}

for the United States and Canada

Kluwer Boston, Inc.

190 Old Derby Street

Hingham, MA 02043

USA

for all other countries

Kluwer Academic Publishers Group

Distribution Center

P.O. Box 322

3300 AH Dordrecht

The Netherlands

This volume is listed in the Library of Congress Cataloging in Publication Data

ISBN-13: 978-94-009-8235-2 e-ISBN-13: 978-94-009-8233-8

DOI: $10.1007 /$ 978-94-009-8233-8

Copyright $@ 1981$ by Martinus Nijhoff Publishers by, The Hague.

Softcover reprint of the hardcover 1st edition 1981

All rights reserved. No part of this publication may be reproduced, stored in a retrieval system, or transmitted in any form or by any means, mechanical, photocopying, recording, or otherwise without the prior written permission of the publisher,

Martinus Nijhoff Publishers bv, P.O. Box 566, 2501 CN The Hague, The Netherlands. 


\section{CONTENTS}

Contributors $\quad$ ix

Introduction

H.W. DE JONG

I. Concentration and competition in food and drinks manufacturing and distribution REMO LINDA

1. The content of the industry and general scheme of analysis 1

2. Global statistical approach $\quad 7$

3. Approach by sample of large enterprises $\quad 12$

4. The place of large multinationals in food and drink relevant markets 19

5. Power interplay between producers and retailers: structures of
prices and mark-ups

6. Conclusion: some future problems for the industry 33

II. The European beer industry: concentration and competition MARIA T. BROUWER 39

1. Introduction 39

2. The development of consumption and production of beer in EEC countries $\quad 40$

3. International trade in beer $\quad 41$

4. Structural changes in the European beer industry 43

5. Determinants of the structure of the beer industry 48

6. Estimates of minimal optimal scales 50

7. Product differentiation and competition $\quad 51$

8. Competition on the 'outdoor' beer market 51

9. Competition on the 'home market' for beer 52

III. The pulp and paper industry: structure and behaviour FABIO GOBBO

1. The basic conditions of the pulp and paper industry $\quad 57$

2. The structure of the pulp and paper industry 66

3. The behaviour of the pulp and paper industry 72

4. The EEC paper industry $\quad 81$

$\begin{array}{ll}\text { 5. Conclusions } & 87\end{array}$ 
IV. The cement industry: studies in public and private control PATRIZIO BIANCHI, DENNIS COLENUTT and DENYS GRIBBIN 93

1. Introduction 93

2. France 95

3. Italy 101

4. United Kingdom 107

5. Federal Republic of Germany 114

$\begin{array}{ll}\text { 6. Conclusions } & 122\end{array}$

V. Structure and performance in the West European steel industry: a historical perspective BO CARLSSON $\quad 125$

1. Introduction $\quad 125$

2. Theoretical background $\quad 126$

3. World steel production and trade in historical perspective 129

4. Western Europe's loss of international competitiveness 135

5. Technical structure as a determinant of international competitiveness 139

6. Relative cost performance 151

7. Summary and conclusions $\quad 152$

VI. Hard coal mining in the EEC countries, especially in Germany HANS OTTO LENEL

1. Developments up to 1957

2. From the coal crisis to the first oil crisis and the years after 163

3. Economic measures and their influence 173

4. The present structure and considerations about the future 178

VII. The automobile industry WILLIAM JAMES ADAMS

1. Introduction $\quad 187$

2. The industries $\quad 187$

3. Market structure 192

4. Performance and public policy 201

VIII.Competition and economic power in the pharmaceutical industry HENK WOUTER DE JONG

1. Introduction 209

2. Characteristics of the market for pharmaceutical products 209

$\begin{array}{ll}3 . \text { Market structure } & 213\end{array}$

4. Competitive behaviour and performance $\quad 222$

5. The divided international market $\quad 230$

6. Policy conclusions $\quad 233$ 
IX. The aerospace industry: problems and policies KEITH HARTLEY

1. Introduction: a study in political economy 237

2. Market structure and performance $\quad 240$

3. Output, productivity and costs in Europe and in the USA 246

4. The case for a European aerospace industry 249

5. Conclusion: some unresolved problems 253

$X$. The computer and data processing industry M. DELAPIERRE, L.A. GÉRARD-VARET, and J.B. ZIMMERMANN

1. Introduction: the international computer industry in Europe 257

2. The industrial capacities $\quad 259$

3. Strategies of electronic data processing firms $\quad 270$

4. National electronic data processing policies $\quad 274$

5. The need for a European industrial electronic data processing policy 283

6. Conclusion 286

XI. Public enterprise in Western Europe and the United States WILLIAM G. SHEPHERD 289

1. The extent and forms of public enterprise $\quad 290$

2. Performance $\quad 301$

3. Brief predictions 311

$\begin{array}{ll}\text { Index } & 321\end{array}$ 


\section{CONTRIBUTORS}

\author{
W.J. Adams, \\ P. Bianchi, \\ M.T. Brouwer, \\ B. Carlsson, \\ D. Colenutt, \\ M. Delapierre, \\ L.A. Gérard-Varet, \\ F. Gobbo \\ D. Gribbin, \\ K. Hartley, \\ H.W. de Jong, \\ H.O. Lenel, \\ R. Linda, \\ W.G. Shepherd,
}

J.B. Zimmermann,
Associate Professor of Economics and Law, The University of Michigan, Ann Arbor, Michigan, USA.

CEPI, University of Bologna, Bologna, Italy.

Lecturer in Economics, University of Amsterdam, Amsterdam, The Netherlands.

Economist, Industriens Utrednings Institut (Industrial Institute for Economic and Social Research), Stockholm, Sweden.

Economic Adviser, Civil Service College, London, United Kingdom.

CEREM - Université de Paris X, Nanterre, France.

GRASCE - Université Aix-Marseille III, Aix-en-Provence, France.

Associate Professor of Applied Economics, University of Bologna, Bologna, Italy.

Economist, The Monopolies Commission, London, United Kingdom.

Reader in Economics, University of York, York, United Kingdom.

Professor of Economics, University of Amsterdam, Amsterdam, The Netherlands.

Professor of Economics, University of Mainz, Mainz, Federal Republic of Germany.

Head of Division Market Structures, Directorate General for Competition, EEC Commission, Brussels, Belgium.

Professor of Economics, University of Michigan, Ann Arbor, Michigan, USA.

CEREM - Université de Paris X, Nanterre, France. 


\section{INTRODUCTION}

The Structure of European Industry is a collection of essays on the economic organization of industrial sectors in Europe, which may serve either of policy makers in business and in Government; and staff and students at Universities. The first group increasingly needs a focus on the longer-term developments of European industry, now that the positive (growth) effects of the economic integration of the sixties have worn off. Restructuring is the current catch word and nobody can deny the necessity and urgency of the task. But it has become a day-to-day affair and there may be a loss of perspective. The second group is growing up in an international environment and should be equipped accordingly.

Many-faceted tasks are involved with serving either depending on the problems which differ according to industries. And here the bewildering complexity of the European industrial scenery strikes. Some of these industries are old fashioned; some are new; some are national in orientation; some have become integrated; some have a competitive structure; some are cartellized or heavily concentrated; some have been interfered with by national Governments, others were free from such policing; etc. Moreover, a number of industries show various combinations of these and other facets at the same time.

Such complexity was to be expected when the venture was started; but it proved to be more pronounced and therefore more difficult to handle than anticipated. The original idea was to have each industry treated by an expert economist according to the well-known triad, structure, conduct and performance, though not organized on a country by country basis, but focusing on the Common Market as a whole. The above-mentioned difficulties, in addition to statistical and language problems have prompted the contributing economists to adopt diverging methods. And so, the reader will find essays which have a developmental and historical slant alongside the structural elements (coal and steel); essays which, like the one on the predominantly nationally organized cement industry, are composed on a comparative basis (with most instructive 
xii

results as the reader will see); essays which discuss mainly the impact on European industry of some leading multi-national giants (computers, aircraft, foods), and essays where the structure, behavior and/or performance of the industry and its firms are highlighted with varying emphasis (motor cars, beer, pharmaceuticals, paper and paper products). The book closes with a comparative discussion of the ways in which European and American economies have organized, regulated and used their public sectors, which, in both areas today, are probably larger than ever before. Thus, the approaches have found their natural beddings, in that they have been given a problem orientation, much more than a schematic or dogmatic one.

What results have we produced? It is not for me to give judgements, so let me emphasize that the authors of the various articles may differ between themselves in their appraisal of what has been achieved. This was clear already at the Conference held at the University of Amsterdam in August 1979, when most of the papers were presented for discussion. Yet, there is a good measure of agreement as to the meaningfulness of the approach chosen and also of the policy measures relating to a number of industries. The economists assembled here are neither laisser-faire devotees, nor dedicated planners; rather, they argue for the prevention of further mergers (as in food and drinks), the control of dominant power (as in pharmaceuticals), a better international and European coordination (as in aircraft and computers), or the promotion of rationalization (steel) in order to save the industry from destruction. Thus, they advocate for the promotion of effectiveness in European industrial structures and policies which are endangered - and not in the last place - by haphazard governmental policies.

Reviewing the enterprise, the editor feels that it was worthwhile, if only because it shows that it can be done, whatever the shortcomings may be. There is no book which discusses European industry from the point of view here chosen, i.e., from the systematic and scientific one, current in industrial organization theory. There was, however, one good example to follow: The Structure of American Industry, edited by Walter Adams, which has run into five editions now. If the present book has not been able to match that one, it has at least shown that so complex a phenomenon as European industry can be mapped out with sufficient scientific rigor, while retaining a realistic perspective.

H.W. DE JONG 